\title{
VII LUBELSKIE SYMPOZJUM NAUKOWE OCHRONA BEZPPIECZEŃSTWA I PORZĄDKU PUBLICZNEGO W PRAWIE RZYMSKIM, LUBLIN 20-22 MAJA 2010 R.
}

W dniach 20-22 maja 2010 r. na Uniwersytecie Marii CurieSkłodowskiej w Lublinie odbyło się VII Lubelskie Sympozjum Naukowe na temat rzymskiego prawa karnego. W roku obecnym odbyło się ono pod hasłem „Ochrona bezpieczeństwa i porządku publicznego w prawie rzymskim”. Konferencję zorganizowały wspólnie dwie katedry UMCS: Katedra Prawa Rzymskiego i Zakład Historii Starożytnej przy współudziale Katedry Prawa Rzymskiego KUL.

Obrady otworzył jeden z gospodarzy konferencji, dr hab. prof. UMCS Krzysztof Amielańczyk, który powitał gości i przypomniał pokrótce historię lubelskich sympozjów. Prof. Amielańczyk przewodniczył także początkowi pierwszej sesji obrad.

Pierwszy referat wygłosiła dr Hanna Appel (UMK), nosił on tytuł Ustawy Gajusza Grakcha o charakterze prewencyjnym: 'ne quis in iudicio circumveniatur' oraz 'de capite civis'. Kolejne prelekcje w tej sesji wygłosili: dr Henryk Kowalski (UMCS) - Ustawodawstwo Pompejusza w zakresie ochrony porzqdku publicznego w 52 roku p.n.e., dr Marzena Dyjakowska (KUL) - Ochrona bezpieczeństwa i porzadku publicznego a rzymskie ustawy o obronie majestatu.

Od tego momentu, do końca pierwszego dnia obrad, ich przewodnictwo objęła prof. dr hab. Maria Zabłocka, Kierownik Katedry Prawa Rzymskiego Uniwersytetu Warszawskiego.

Tę część obrad rozpoczął prof. Krzysztof Amielańczyk, Sicarii zjawisko rzymskiego bandytyzmu w okresie późnej republiki rzymskiej. Referent przedstawił sposoby walki z rozprzestrzenianiem się przemocy u schyłku republiki rzymskiej. Po wygłoszeniu wszystkich odczytów w tej sesji, prowadząca otworzyła dyskusję.

W drugiej części sesji wygłoszono kolejne referaty. Rozpoczęła dr Elżbieta Loska (UKSW) tekstem 'Contra tribunum plebis furiosum et audacem'. Spory między urzędnikami zagrożeniem dla bezpieczeń- 
stwa republiki?. Następnie dr Paulina Święcicka (UJ) wygłosiła referat 'Propter tranquillitatem animorum civium et securitatem publicam'. Grecka myśl, obyczaje i religia jako zagrożenie dla republikańskich obyczajów i porzadku publicznego. Wzbudził on kontrowersje podczas dyskusji. Dr Przemysław Kubiak (UŁ) mówił na temat: Ograniczanie 'ius vitae ac necis' właścicieli niewolników na przykładzie wymierzania kar wykonywanych na arenie, analizując tekst D. 48,8,11,1-2. Tę sekcję zakończyła dr Joanna Misztal-Konecka (KUL), z referatem 'Civitas interdicta monachis'. Mnisi zagrożeniem dla porzqdku publicznego? Także po tej części obrad odbyła się dyskusja. Cenna w niej była zwłaszcza możliwość obserwacji różnic w podejściu do interpretacji tekstów źródłowych pomiędzy historykami a prawnikami. Różnica ta może zaowocować w przyszłości szerszym spojrzeniem na zachowane źródła u obu stron dyskusji.

Drugi dzień sympozjum otworzył gospodarz, prof. dr hab. Marek Kuryłowicz, kierownik Katedry Prawa Rzymskiego UMCS.

Drugiej sesji obrad przewodniczył ks. prof. dr hab. Antoni Dębiński, Kierownik Katedry Prawa Rzymskiego Katolickiego Uniwersytetu Lubelskiego. Jako pierwszy tego dnia referat wygłosił prof. dr hab. Marek Kuryłowicz (UMCS), Publiczne porzqdki i nieporzqdki pogrzebowe we wczesnym cesarstwie rzymskim. Dr Maciej Jońca (KUL) mówił o cesarskich regulacjach prawnych dotyczących grobowców w prelekcji Zmartwychwstanie Chrystusa a nietykalność grobu w świetle ,Inskrypcji z Nazaretu”. Kolejne referaty w tej sekcji przedstawili: dr Aldona Jurewicz (UWM), 'Hospitium' $i$ 'patrocinium' w'Lex Coloniae Genetivae Iuliae' (c.130-131) oraz mgr Klaudia Jerz (UMCS), Stużby porzadkowe w komediach Plautusa. Po wysłuchaniu referatów ks. prof. Dębiński otworzył i moderował dyskusję.

Kolejnej części obrad przewodniczyła Anna Pikulska-Radomska, kierownik Katedry Prawa Rzymskiego Uniwersytetu Łódzkiego. Jako pierwszy wystapił dr Ireneusz Jakubowski (UŁ), $Z$ zagadnien' 'furtum' w Instytucjach Gajusa i Instytucjach Justyniana. Po nim referat Wykonawcy kary śmierci w państwie rzymskim wygłosiła mgr Anna Pawłowska (ALK). Kolejnym prelegentem był mgr Andrzej Chmiel (UMCS), Ochrona bezpieczeństwa właścicieli niewolników w świe- 
tle SC Silanianum - zagadnienia dowodowe. Następnie mgr Tomasz Tadajczyk (UŁ) przedstawił sytuację medyków w starożytności w tekście Przywileje lekarzy a ochrona porzadku publicznego w starożytnym Rzymie. Po zakończeniu referatów, przewodnicząca otworzyła dyskusję.

Trzecią sesję obrad moderował prof. dr hab. Jan Zabłocki, Kierownik Katedry Prawa Rzymskiego Uniwersytetu Kardynała Stefana Wyszyńskiego w Warszawie. Pierwszy referat przedstawił mgr Tomasz Banyś (UŁ), Wybrane problemy operacji policyjnych armii rzymskiej. Historyczne podejście w tej sekcji prezentował dr Dariusz Słapek (UMCS), który mówił o widowiskach sportowych ( 'Spectaculi spectantes' - o milczeniu źródet i naturze prawa rzymskiego). Dr Jacek Wiewiorowski (UAM) referował na temat Ochrony porzqdku publicznego jako przesłanki reform zarzqdu prowincjonalnego za Justyniana Wielkiego $w$ latach 535-536. Dr Anna Tarwacka (UKSW) przedstawiła przebiegłość Werresa w referacie 'In conspectu legum libertatisque moriatur'. Sprawa Publiusa Gaviusa a kompetencje namiestnika do ochrony porzqdku publicznego $w$ prowincji. Dr Renata ŚwirgońSkok (URz) zajęła się Prawnokarnq ochrona granic gruntów państwie rzymskim, a dr Adam Świętoń (UWM) Rola 'agentes in rebus' $w$ wykrywaniu i zwalczaniu spisków przeciwko władzy cesarskiej w późnym Cesarstwie Rzymskim. Obrady tej sekcji zamknął mgr Piotr Kołodko (UwB), omawiając kompetencje prefekta ('Praefectus vigilum' jako strażnik bezpieczeństwa publicznego w starożytnym Rzymie). Nad przedstawionymi referatami odbyła się dyskusja.

Na koniec drugiego dnia konferencji odbyła się inscenizacja fragmentu sztuki Plauta Żotnierz Samochwat, a po niej prezentacja walk gladiatorów przygotowana przez Koło Naukowe Amatorów Antyku działające przy Zakładzie Historii Starożytnej UMCS.

Elżbieta Loska*

* Uniwersytet Kardynała Stefana Wyszyńskiego. 